\title{
РЕПРЕЗЕНТАЦІЯ ПАРАМЕТРІВ НЕВЕРБАЛЬНОЇ КОМУНІКАЦІї У ТВОРАХ МИХАЙЛА КОЦЮБИНСЬКОГО
}

\author{
ТЕТЯНА ОСІПОВА \\ Харківський національний педагогічний університет імені Г. С. Сковороди, \\ Харків - Україна \\ REPREZENTACJA PARAMETRÓW KOMUNIKACJI NIEWERBALNEJ \\ W UTWORACH MYCHAJŁA KOCIUBYNSKIEGO \\ TETIANA OSIPOWA \\ Charkowski Narodowy Uniwersytet Pedagogiczny im. H. Skoworody, \\ Charków - Ukraina
}

STRESZCZENIE. Międzydyscyplinarny charakter współczesnego językoznawstwa uwarunkował nowe spojrzenie na tekst autorski jako wskaźnik elitarności osobowości językowej. W artykule przeanalizowano literackie teksty M. Kociubynskiego charakteryzujące się udanym połączeniem sposobów opisu i wyrażania emocji za pomocą niewerbalnych środków komunikacji, oddających treści stosownie do różnorodnych funkcji komunikacji i tych, które kształtują różne sensy komunikatywne, co z kolei rozwija kompetencje językowe.

\section{REPRESENTATION OF NON-VERBAL COMMUNICATION PARAMETERS IN MICHAEL KOTSYUBINSKIY'S WORKS}

\section{TETIANA OSIPOVA}

H. S. Skovoroda Kharkiv National Pedagogical University, Kharkiv — Ukraine

ABSTRACT. Interdisciplinary character of modern linguistics determined a new look at an authorial text as the indicator of a language personality elitism. The article deals with M. Kotsyubinskiy's literary texts. They successfully combine the descriptive and expressive means of rendering emotions in non-verbal communication, verbalized in various communicative situations. Decoding of different created communicative senses facilitates discursive competence in general.

\footnotetext{
инкретизм сучасної мовознавчої науки зумовлює народження нових наукових парадигм, напрямів, гіпотез і теорій. Інноваційність може викликати гарячі дискусії, що, як відомо, є потужним стимулом до розвитку науки. Лінгвістична прагматика вдихнула в мовознавство нові сили, надала дослідникам можливість спостерігати окреслені ними мовні явища, поглибити, узагальнити, а подекуди й заповнити лакуни мовознавчої науки, що пов'язані iз відповіддю на питання, для чого функціонують мовні знаки в дискурсивному мовному просторі, які одиниці мови доцільніше використовувати в тій чи тій комунікативній ситуації, дискурсивній практиці відповідного народу з урахуванням стратегій і тактик комунікації в межах відповідної ситуації, лінгвокультури загалом.
} 
Взаємодія традиційної лінгвістики з психолінгвістикою, комунікацією, риторикою, функційною стилістикою та іншими науками зумовила новий погляд на авторський текст як на індикатор елітарності мовної особистості, а також започаткувала теорію мовної особистості, ,що характеризується суперечністю співвідношення стабільних і змінних елементів, сталістю мотивацій і здатністю підпорядковуватися зовнішнім впливам"1, що потребує, відповідно, й багатоаспектного вивчення.

У цьому напрямку застосовуються як комплексний, так і вузькоаспектний підходи, що їх утілила професор Т. Космеда в монографіях Комунікативна компетенція Івана Франка: міжкультурні, інтерперсональні, риторичні виміри ${ }^{2}$ та Ego i Alter Ego Tараса Шевченка в комунікативному просторі щоденникового дискурсу ${ }^{3}$.

Дослідженню мовної особистості сьогодні приділяють чималу увагу як в Україні, так і за її межами, зокрема широкому загалу філологів відомі наукові розвідки О. Забужко ${ }^{4}$ Ю. Шевельова ${ }^{5}$, Л. Ушкалова ${ }^{6}$, С. Заварзіної, Н. Сологуб ${ }^{8}$ та ін. Теоретико-методологічне підгрунтя досліджень, що виконуються в окресленому ракурсі, становлять насамперед праці таких сучасних українських і російських дослідників, як Ю. Караулов, В. Карасик, Т. Космеда, Т. Кочеткова, В. Шаховський та ін.

Михайло Коцюбинський уніс в українську літературу нову манеру письма, що характеризується пошуками "найвиразніших, найекономніших, найбільш відповідних власним естетичним настановам засобів вираження". Мовна індивідуальність М. Коцюбинського виявляється в майстерності „об'єднання композиційно-мовленнєвих форм і типів мовлення, зіставлення будови твору 3 формами й елементами загальнонаціональної мови і $з$ позамовними засобами мовленнєвого спілкування"

Мовний аналіз авторських текстів письменника ілюструє їхній потужний фоностилістичний потенціал. Стилістична фонетика, як відомо, вивчає засоби звукової організації мовлення, виокремлює найдоцільніші способи використання природних і функціональних ознак звуків для певного типу мовлення. Звуки належать до національно маркованих одиниць мови. Фонетика кожної мови репрезентує іiі оригінальність і самобутність, яку не завжди помічають пересічні носії мови, що виявляється насамперед у вигукових конструкціях, омовленні жестів, голосу, звуків природи, довкілля і под.

${ }^{1}$ T. Космеда, Ego i Alter Ego Tapaca Шевченка в комунікативному просторі щзоденникового дискурсу, Дрогобич 2012, с. 25.

2 Див.: Т. Космеда, Комунікативна компетениія Івана Франка: міжкультурні, інтерперсональні, риторичні виміри, Львів 2006.

${ }^{3}$ Див.: Т. А. Космеда, Ego i Alter Ego...

${ }^{4}$ Див.: О. Забужко, Notre Dame d'Ukraine: Украӥнка в конфлікті міфологій, Київ 2007.

${ }^{5}$ Ю. Шевельов, Вступна стаття, [в:] Олександр Потебня. Мова. Наиіональність. Денаціналізація. Статті і фрагменти, Нью-Йорк 1992, с. 31. Ю. Шевельов, Вступна стаття, [в:] Олександр Потебня. Мова. Національність. Денащіналізаиія. Статті і фрагменти, Нью-Йорк 1992, c. 31.

${ }^{6}$ Л. В. Ушкалов, Григорій Сковорода: семінарій, Харків 2004.

${ }^{7}$ С. В. Заварзіна, Щоденники В. Винниченка та Ф. Достоєвського: до питання жанрової специфіки, [в:] „Вісник Харківського національного університету імені В. Н. Каразіна”, Серія: Філологія. Харків 2005, № 659, вип. 44, с.132-136.

${ }^{8}$ Див.: Н. М. Сологуб, Мовний портрет Яра Славутича, Київ 1999.

9 Див.: А. Ю. Скачков, Лінгвостилістичні особливості портретних описів у творах М. Коцюбинського, Харків 2007.

${ }^{10}$ Там само. 
Писемне мовлення М. Коцюбинського — це „жива матерія”, що вербалізує зовнішній світ, омовлюючи його категоріями, думками, інтерпретаціями авторського світогляду, світобачення й світосприйняття, своєрідно репрезентуючи МКС, відтворюючи іiі відповідними художньо-мовними зокрема й експресивними засобами. Нагадаємо, що „,експресивність тексту — це його здатність впливати на свідомість та поведінку реципієнта. Ядром експресивності тексту є його емотивність - характеристика мовних засобів, призначених для посилення емоціогенності змісту тексту" 1 , що зреалізовується й за допомогою вербалізації емоційно значущих звуків — звукових інтер'єктивів, вигуківспонукань, модальних часток, звуконаслідувальних комплексів, омовлення звукових емоційних реакцій людини, що не так часто привертає увагу науковців. Хоч в останній час помічено тривожну тенденцію до використання запозичених вигуків типу Ував! Уnc! і под. Це негативний процес, який простежуємо в сучасному дискурсі українців.

Дослідники вважають, що „обраний” мовцем мовний засіб для репрезентації авторських емоційних станів та адекватних емоційних реакцій адресата, також належить до експресивних засобів комунікації, що виконують функцію активізації адресата під час трансформації установок та оцінок мовця ${ }^{12}$.

Комунікація завжди обумовлена екстралінгвальними чинниками. В. Апресян і Ю. Апресян відзначають, що емоції нелегко укласти в слова, оскільки „онтологічна складність зумовлює складність лінгвістичну: слову, що позначає емоції, практично неможливо надати пряме лексикографічне тлумачення"13 (пер. автора - Т. О).

Спираючись на зазначені постулати, вчені пропонують розмежовувати мову опису емоцій та мову вираження емоцій, що реалізуються емоційно зарядженою та контекстуально зумовленою лексикою, виконуючи, відповідно, номінативну й прагматичну функції ${ }^{14}$ (курсив автора — Т. О). Сьогодні розробляють й самостійний напрям мовознавства — лінгвоемоціологію (напр., російський дослідник В. Шаховський, українська дослідниця В. Сліпецька) ${ }^{15}$. „Серед аспектів, що визначили розвиток деяких пріоритетних напрямів сучасної лінгвістики емоцій, можна виокремити лінгвокультурологію емоцій, концептологію емоцій, гендерну емоціологію, емотивність тексту та деякі інші, що вирішують проблеми реалізації емоцій, які виражаються в мові, динаміку мовного коду, механізми декодування власних емоцій та емоцій інших людей у процесі комунікації'16.

Невербальний параметр суттєво нівилює зазначену мотивацію, адже висновок про емоцію можна зробити тільки за умови аналізу конкретної ситуації. Урахування системи чинників „вербаліка + невербаліка + ситуація роблять зрозумілим те, що виражається, й для спостерігача, й для комуніканта" 17 , однак цей параметр у структурі мовної особистості науковці не виокремлюють і не описують.

${ }^{11}$ В. А. Маслова, Некоторые онтологические аспекты эмотивности текста, [в:] Язык и эмоции, Сборник науч. трудов, Волгоград 1995, с. 184-191.

${ }^{12}$ М. Ю. Олеш ков, Моделирование коммуникативного процесса, Нижний Тагил 2006, с. 228.

13 В. Ю. Апресян, Ю. Д. Апресян, Метафора в семантическом представлении эмоиий, [в:] „Вопросы языкознания”, 1993, № 3, с. 27-35.

${ }_{14}$ М. Ю. Олешков, Моделирование коммуникативного проиесса, Нижний Тагил 2006, c. $228-229$.

${ }^{15}$ В. Сліпецька, Паремії як поведінкові мовленнєві формули репрезентаиї негативних емоиій $і$ станів, [в:] „Мова. Культура. Взаєморозуміння”, за ред. Т. А. Космеди, вип. III, Дрогобич 2013, с. 47-53.

${ }^{16}$ В. И. Шахов ский, Лингвистическая теория эмоций, Москва 2008, с. 20.

${ }^{17}$ T. А. Космеда, Ego i Alter Ego..., c. 53. 
Унаслідок цього в сучасному науковому дискурсі досить активно функиіонує тавтологічна конструкція вербалізація невербаліки, що знаходиться на шляху терміноствердження і за умови розвитку галузі претендує на роль терміна $^{18}$.

Омовлення параметрів невербальної комунікації є одним із засобів посилення експресії художнього тексту, вияву індивідуально-авторських особливостей мови письменника, елітарності його ідіостилю ${ }^{19}$.

Вербалізація паралінгвальних, зокрема екстралінгвальних засобів (cмix, плач, зітхання тощо) в процесі опису комунікативної поведінки людини надає можливість діагностувати іiї внутрішній стан, приховані думки, іiї ставлення до оточення тощо ${ }^{20}$. Однак ідентифікація емоції в комунікативній ситуації зумовлена деякою неоднозначністю в аспекті застосування одного й того самого мовного засобу.

Тексти М. Коцюбинського привертають увагу не лише з огляду на засоби омовлення (вербалізації) екстралінгвальних чинників комунікації, але й з огляду на своєрідність їхнього мовного вираження, що може посилювати експресію художнього тексту, порівн.: Ха-ха-ха!.. a-ха-ха! Вона не могла здержати сміху, непереможного, 'яного, щчо клекотів у грудях і лиш, як піну, викидав окремі слова: - Ха-ха-ха!.. всіх... викоренити... ха-ха-ха!.. щуоб і на насіння... всіх!. a-ха-ха!.. - вона аж хлипала (М. Коцюбинський, Сміх) - автор удається до образного, метафоричного опису манери сміху, підкріплюючи його звуковим інтер'єктивним комплексом.

Вербалізація динамічних засобів, зокрема номінація емоційних рухів, у поєднанні з вигуковими елементами ілюструють динаміку комунікативної поведінки відповідної мовної особистості, репрезентованої в художньому тексті, порівн.: „Нехай буде так! — плескав в долоні Чугайстир, і присідав до землі, $і$ крутився круг себе. - Ха-ха-ха! - хльоскав себе по стегнах Іван” (М. Коцюбинський, Тіні забутих предків).

Дискурсивна компетенція як така, що встановлює зв'язок між адресантом і адресатом, пов’язана 3 категорією мовної особистості, і як „вид синкретичної компетенції, що сформувалась унаслідок уваги до дискурсу як операційного поняття сучасного лінгвістичного знання", потребує вивчення проблеми ситуаційного функціонування мови ${ }^{21}$.

Специфіка манери репрезентації екстралінгвальних засобів у різних комунікативних ситуаціях зумовлює певний ступінь дискурсивної компетенції читача, порівн.: 1) Хома сміявся і погано сміявся: - Стережете панське добро? Ха-ха! Пильнуйте, пильнуйте, щзоб не пропало. Подякує пан, як поверне назад. Аякже... (М. Коцюбинський, Fata morgana) — контекст висвітлює одне із зна-

18 Т. Ф. Осіпова, Вербалізаиія „невербалики”: інноваційні словотвірні тендениії в системі мовознавчої термінології, [в:] Лексико-грамматические инновации в современных словянских языках, Днепропетровск 2013, с. 221-223.

19 Т. А. Космеда, Т. Ф. Осипова, Индивидуально-авторское воспроизведение параметров невербальной коммуникации в идиостиле писателя как элитарной языковой личности, [в:] Язык и культура в эпоху глобализации в 2 m., СПб. 2013, вып. 1, т. 2, с. 44-53.

${ }^{20}$ Т. Ф. Осіпов а, Метамова невербальної комунікації: „, вербалізація невербаліки” як засіб реалізації мовного коду (на матеріалах авторських текстів I. Франка, Т. Шевченка, А. Чехова), [в:] „Мова. Культура. Взаєморозуміння”, за ред. Т. А. Космеди, Дрогобич 2013, вип. III, c. $62-71$.

21 Л. Н. Синельникова, Компетенции как критерии идентичности языковой личности, [в:] „Учёные записки Таврического национального университета, Сер. Филология. Социальные науки", Симферополь 2010, т. 23 (62), № 2, ч. 2, с. 354-364. 
чень лексеми погано, що розуміємо як саркастичний сміх, сміх безнадії й розчарування; 2) Ха-ха-ха!.. От козак-разкозак!.. — реготався Остап. — Хa-ха-ха!.. (М. Коцюбинський, Дорогою ціною) - розкотистий і відкритий сміх реалізується описовою одиницею реготався; 3) Om се вигадав! Щоб жінка та чоловіка била - та се ж беззакон, без пардон!.. Зроду такого не було... хе-хе-хе... непевно якось сміявся Іван, немов хотів підбадьорити себе (М. Коцюбинський, Ціпов'яз) - такий сміх автор інтерпретує як сміх невпевненості, самозаспокоєння; 4) Хе-хе-хе!... О, бодай тебе, щуо вигадав, - хехекав Іван, мов булькав із повної пляики (М. Коцюбинський, Ціпов'яз) - опис специфічної манери сміху увиразнюється образним порівнянням, що його використовує автор.

Комунікативна варіативність вербалізації екстралінгвальних параметрів $\epsilon$ однією з характерних ознак ідеостилю М. Коцюбинського, що виражається в поєднанні засобів репрезентації емоцій, зокрема мови опису й мови їхнього вираження.

Експресивності тексту автор досягає також за рахунок омовлення невербальних засобів, що мають більше підтекстовий характер, порівн.: Цить, доню, цить ... не сварися з богом ... потерпімо... (М. Коцюбинський, Ціпов 'яз); Цить! - накинулась на Андрія Маланка (М. Коцюбинський, Fata morgana); Натовп захвилювався. Ти! Тц! (М. Коцюбинський, Fata morgana) - відімперативи Цить! Ти! ілюструють, як відомо, жести на позначення заборони говорити в певній комунікативній ситуації і $є$ настільки однозначними та потужними за енергетикою, що не потребують вербального авторського коментаря. Звуковідтворення свисту та зітхання надають тексту емоційної інтенсивності, поетизуючи висловлення, порівн.: Ф’ю-ю! - свиснув Антоша. - нема вже барона в маєтку, тай сам утік... Страх, щзо діється всюди, а тут щзе ви, татку, з своїм лібералізмом. - Ах, ах! - зімхнула хазяйка дому (М. Коцюбинський, Коні не винні).

Дискурсивна компетенція вимагає від читача вміння правильно трактувати вербалізовані невербальні дії відповідно до контексту їхнього уживання. Невербальний знак може мати синкретичну природу й у відповідних комунікативних ситуаціях репрезентує адекватні до цих ситуацій емоції, порівн.: Чи ж божевільний? - спинивсь урешті Семен. - Тьфу, відкаснись, сатано! (М. Коцюбинський, Ціпов'яз); Тьху, тьху, тьху! Тричі тьху на твою землю! Хай вона тобі западеться! Не наймуся я й не буду в землі ритися. Вона витягла з мене усі сили та й пустила на старість голого. Тьху, ще раз тьху на неї... (М. Коцюбинський, Fata morgana) — автор тут вербалізує містично-ритуальний тричі спльовувати, що репрезентує мовленнєвий жанр прокляття. Такий самий невербальний знак, „украплений” в інший контекст, може сприяти моделюванню іншого комунікативного смислу, порівн.: I він тоді пив пиво ... На готові. Чисте, золоте, холодне пиво... Тъху! Аж слина котиться... (М. Коцюбинський, Fata morgana) — в цьому разі автор репрезентує реакцію розчарування в ситуації бажаної нездійсненності.

Індивідуально-авторська майстерність М. Коцюбинського виявляється також в умінні каскадного поєднання вербального й невербального компонентів, що сприяє підвищенню експресивності тексту, порівн.: Пані Наталі той крик розривав груди. Ах, тихше... тихше... почують... - благали ії очі і болісний вираз. Притискала до грудей руки і все з жсахом иептала: - O, пане докторе... будьте ласкаві... Ах, боже... Але доктор не слухав. - Беріть револьвер, кричав він, - і ходім зараз! - Я не маю револьвера, сердито скрикнув Чубин- 
ський. - Фю-ю! - ажс свиснув доктор (М. Коцюбинський, Сміх) - омовлення невербальних параметрів - сили, потужності голосу (паралінгвістика), погляду (окулесика), постави, пози (кінесика), шепоту й свисту (екстралінгвістика), а також паралельне використання їхньої звуковідтворювальної форми ідентифікують креативні тексти М. Коцюбинського й визначають особливості його індивідуального стилю.

Знаковим видається й те, що деякі назви творів письменника окреслюються відповідними параметрами невербаліки (напр. Сміх). Використання ключових номінацій, що окреслюють певні процеси невербаліки, в сильній текстовій позиції, до якої традиційно відносять заголовки текстів, ще потребують дослідження, оскільки вони, як видається, містять чималий прагматичний потенціал.

М. Коцюбинський, як бачимо, добре відчував і відповідно моделював, наповнював оригінальними, національно забарвленими формами засоби вербалізації емоцій і почуттів, що вмонтовано в ,живу тканину” його художнього текст, репрезентує особливості сучасної йому дискурсивної практики українців.

Отже, параметри невербальної комунікації, вербалізовані в художньому тексті, прагматично його наповнюють, візуалізуючи сюжети й „оживляючи” персонажі, виразно реалізують авторські замисли та інтенції. Невербальні засоби комунікації репрезентуються в мовленні як відповідні коди, для розуміння яких необхідно володіти належним рівнем низки компетенцій, насамперед комунікативної, дискурсивної, емоційної, етнокультурної. Комунікативні смисли, змодельовані внаслідок „омовлення невербаліки” („вербалізації невербаліки”) поглиблюють комунікативну й мовну компетенцію учасників спілкування, розширюють мовний і комунікативний досвід.

Володіння мистецтвом створювати естетичні тексти характеризують автора як елітарну мовну особистість, для якої формування комунікативної компетенції у всіх іiї проявах — процес постійного самовдосконалення.

Зазначені лінгвістичні постулати актуалізують положення Ф. фон Гумбольдта, молодограматичного наукового напрямку, Ф. де Соссюра, Б. де Куртене, Л. Щерби, В. Виноградова, Н. Хомського та інших класиків лінгвістичної думки стосовно необхідності вивчати індивідуальне мовлення окремих мовних особистостей як представників певної лінгвістичної спільноти.

Невербальна комунікація, як і кожна система кодів, має національну та контекстуальну специфіку, яку можна простежити на дискурсивному рівні, зокрема в художніх, публіцистичних, ораторських текстах креативних представників слов'янської лінгвокультури, що складають слов'янську мовну еліту. Зазначене й визначає перспективу цього дослідження. 